\title{
Effect of ghrelin variants on weight loss after dietary/exercise intervention*
}

\author{
Jaroslav A. Hubacek, Pavel Suchanek, Rudolf Poledne \\ Institute for Clinical and Experimental Medicine, Cardiovascular Research Centre, \\ Prague, Czech Republic
}

\begin{abstract}
Hubacek JA, Suchanek P, Poledne R (Institute for Clinical and Experimental Medicine, Cardiovascular Research Centre, Prague, Czech Republic). Effect of ghrelin variants on weight loss after dietary/exercise intervention. Cor Vasa
\end{abstract} 2007;49(6):213-215.

Introduction: Ghrelin is an endogenous hormone expressed predominantly in the stomach. Ghrelin controls growth hormone secretion and also affects the body's energy balance. We have analyzed the association of ghrelin variants with body weight changes after dietary/exercise intervention in healthy overweight females.

Methods: Ghrelin variants Arg51 > Gln, Leu72 > Met and Gln90 > Leu were analyzed by PCR-RFLP in 80 overweight (BMI $31.1 \pm 3.0 \mathrm{~kg} / \mathrm{m}^{2}$ ) females aged 25-55 years. Development of body weight and plasma lipids were analyzed in subgroups divided according to ghrelin genotypes.

Results: Carriers of the Met72Met genotype were resistant to dietary/exercise intervention. They lost $1.5 \mathrm{~kg}$ compared to Leu72 carriers $(5.3 \mathrm{~kg})$. Other variants had no effect on body weight changes. Plasma lipids were not changed significantly between subgroups divided according to ghrelin variants.

Conclusions: Common variants in ghrelin may have an effect on changes of body weight after behavioral intervention. However, the frequency of Met72Met carriers in the population is very low and results need to be confirmed in future studies. Key words: Ghrelin - Genetic polymorphism - Body weight - Diet - Exercise

Hubacek JA, Suchanek P, Poledne R (Institut klinické a experimentální medicíny, Centrum výzkumu kardiovaskulárních onemocnění, Praha, Česká republika). Vliv variant genu pro ghrelin na úbytek tělesné hmotnosti po úpravě stravy/po zátěžové intervenci. Cor Vasa 2007;49(6):213-215.

Úvod: Ghrelin je endogenní hormon exprimovaný převážně v žaludku. Ghrelin řídí sekreci růstových hormonů a ovlivňuje i energetickou bilanci organismu. Hodnotili jsme asociaci mezi variantami genu pro ghrelin a změnami tělesné hmotnosti po úpravě stravy/po fyzické zátěžové intervenci u zdravých žen s nadváhou.

Metody: Varianty genu pro ghrelin Arg51 > Gln, Leu72 > Met a Gln90 > Leu byly analyzovány technikou PCR-RFLP u 80 žen s nadváhou (BMI $31,1 \pm 3,0 \mathrm{~kg} / \mathrm{m}^{2}$ ) ve věku 25-55 let. Změny tělesné hmotnosti a koncentrací plazmatických lipidů byly analyzovány $\mathrm{v}$ podskupinách podle genotypů pro ghrelin.

Výsledky: Nositelé varianty Met72Met vykazovali rezistenci vưči úpravě stravy/fyzicky zátěžové intervenci. Jejich tělesná hmotnost se snížila o 1,5 kg ve srovnání s nositeli varianty Leu72 (5,3 kg). Ostatní varianty na změny tělesné hmotnosti vliv neměly. Hodnoty plazmatických lipidů u podskupin rozdělených podle variant genu pro ghrelin se statisticky významně nezměnily.

Závěry: Běžné varianty genu pro ghrelin mohou mít po behaviorální intervenci vliv na změny tělesné hmotnosti. Počty nositelů varianty Met72Met v populaci jsou však velice nízké a výsledky musí potvrdit další studie.

Klíčová slova: Ghrelin - Genetický polymorfismus - Tělesná hmotnost - Strava - Tělesná zátěž

Address: Ing. Jaroslav A. Hubacek, CSc., IKEM-DEM, Laboratory for Molecular Genetics, Videnska 1958/9, 14021 Prague 4 , Czech Republic, e-mail: jaroslav.hubacek@medicon.cz

\section{INTRODUCTION}

Obesity is one of the main health problems in most populations worldwide and a large proportion of obese individuals die from overweight-related complications. Obesity results from simultaneous effects of adverse environmental factors (abundant energy intake, low physical activity) and genetic factors.
Interactions between environmental and genetic factors have not been intensively analyzed yet.

One of the candidate genes, which can influence weight loss, is the ghrelin gene. ${ }^{(1)}$ The main source of ghrelin secretion is stomach, but ghrelin is also produced by the hypothalamus, pituitary gland, duodenum, and the kidney. Ghrelin is an endogenous peptide composed, in its active form, of 28 amino 
acids (the ghrelin precursor, preproghrelin, has 117 amino acids and a second hormone, obesitine, is derived from the same precursor); in humans, it circulates in the plasma at concentrations $~ 800-1,000 \mathrm{pg} / \mathrm{mL} .{ }^{(2)}$

Ghrelin is a ligand for the growth hormone secretagogue receptor that stimulates growth hormone release and affects the sleep pattern, eating habits, amount of food ingested, and the body's energy balance. ${ }^{(1)}$ The role of ghrelin in obesity induction had been documented in animal experiments. In animals, administration of ghrelin leads to increased food intake and decreased fat utilization and energy expenditure. ${ }^{(2)}$

In humans, the plasma levels of ghrelin are inversely correlated with body mass index and the highest plasma levels were found in patients with anorexia and the lowest in obese subjects. ${ }^{(3,4)}$ The plasma levels of ghrelin are elevated in the preprandial state; ${ }^{(5)}$ when injected to healthy volunteers, ghrelin induced a sensation of hunger. ${ }^{(6)}$

In the coding part of the human gene for ghrelin, three polymorphisms have been identified to date (Arg51 > Gln, Leu72 > Met, and Gln90 > Leu). ${ }^{(7,8)}$ All these variants were analyzed in a couple of studies in an effort to assess their effect on obesity development and/or the genetic determination of body weight. The Leu72 > Met and Gln90 > Leu variants have been suggested, but not conclusively confirmed, to play a role in the genetic determination of body weight.

We sought to establish if these variants have an effect on weight loss after dietary/physical activity intervention.

\section{METHODS}

A total of 80 overweight (BMI $31.1 \pm 3.0 \mathrm{~kg} / \mathrm{m}^{2}$ ) females aged between 25 and 55 years participated in a nineweek intervention study involving diet modification (dietary intake $<8000 \mathrm{kcal}$ ) and increased physical activity (one-hour 4 times a week, twice with a personal trainer in a fitness center and twice outdoors activity, walking or cycling). For more detail about the study protocol, see Dvorakova-Lorencova et al. ${ }^{(9)}$

DNA was isolated by standard salting-out method. ${ }^{(10)}$ Three ghrelin variants were analyzed by PCR and restriction analysis of the PCR products, as described in more details elsewhere (Hubacek et al. "Variants within the ghrelin gene - association with HDL-cholesterol, but not with body mass index in a large Caucasian population", submitted February 2007).

Anthropometric parameters were measured by a trained staff. The lipoprotein and biochemical parameters were measured in the WHO Regional Lipid Reference Centre, Institute for Clinical and Experimental Medicine, Prague on a COBAS MIRA (Hoffman-La Roche, Basel, Switzerland) autoanalyzer using conventional enzymatic methods with reagents from Hoffmann-La Roche.

For statistical analysis, the individuals were divided to subgroups according to their ghrelin genotype. For all variants, statistical analysis was performed either under the dominant (carriers of the allele 1 vs. 22 homozygotes), codominant (11 vs. 12 vs. 22 ) or recessive model (carriers of the allele 2 vs. 11 homozygotes). Statistical analysis was performed by the paired $t$-test.

\section{RESULTS AND DISCUSSION}

Individual ghrelin alleles are not in linkage disequilibrium and all three ghrelin polymorphisms are in Hardy-Weinberg equilibrium. The allelic frequencies of all three analyzed variants were similar to those of others insofar that the analyzed populations were of the same ethnicity.

The biochemical parameters analyzed (total, LDL-, HDL-cholesterol, triglycerides, insulin, and blood glucose) did not change in relation to ghrelin variants.

After intervention, all females lost their body weight over a wide range from $1.2 \mathrm{~kg}$ to $12.9 \mathrm{~kg}$.

The subgroups divided according to the ghrelin Arg51 > Gln and Gln90 > Leu variants were not significantly different in their mean weight loss.

Carriers of at least one Leu72 allele showed a mean weight loss of $5.3 \mathrm{~kg}$. All females lost at least $2.5 \mathrm{~kg}$. In contrast, two females relatively resistant to intervention were both Met72Met homozygotes and they lost $1.5 \mathrm{~kg}$ only. Although the number of identified Leu72Leu homozygotes was very low $(\mathrm{n}=2)$, the difference reached statistical significance at $p<0.05$.

As all the volunteers were highly motivated to lose weight, we do not suspect them they were not following the dietary recommendations. However, we cannot rule out the possibility they have different degrees of sensation of hunger. While no functional studies of individual ghrelin variants have been performed to date, Met72Met homozygotes have been reported to show elevated plasma ghrelin levels compared to others ${ }^{(11)}$ and, when injected to healthy volunteers, ghrelin induced a sensation of hunger. ${ }^{(6)}$ In animal experiments, ghrelin injection leads to increased food intake and decreased fat utilization and energy expenditure. ${ }^{(2)}$ These results are in agreement with our observations, thus we take our results for real and not only an artifact caused by a low number of analyzed individuals.

Our results will be quite difficult to verify. We have screened a large population sample for the ghrelin variants (Hubacek et al. "Variants within the ghrelin gene - association with HDL-cholesterol, but not with body mass index in a large Caucasian population", submitted February 2007) and, within the total number of 1,368 analyzed females, we identified only 7 carriers (a frequency $\sim 0.5 \%$ ) of the Met72Met genotype.

Thus, in the Czech population, where obesity is one of the most serious health risks (according to the MONICA study in 2000, 29.5\% and $28.1 \%$ of men and women, respectively, were obese while overweight afflicted $45.9 \%$ of men and $32.4 \%$ women), this variant will not play an important epidemiological role. What our data do show is that there are some individuals who are genetically predetermined to increased food intake and to thrifty metabolism leading to the increased fat storage.

To date, ghrelin variants have been analyzed in association studies only.

Data obtained by Ukkola et al. ${ }^{(8)}$ indicated that the Arg51Gln variant could be associated with the etiology of obesity, as the authors found carriers of the Gln allele in obese females only with a frequency of $6.3 \%$. 
The same authors ${ }^{(11)}$ later published the results of three different studies (Quebec Family Study, HERITAGE Family Study and Swedish Obese Subject study), and, although the results were not homogeneous throughout all three studies, the Met72 allele was suggested to be associated with favorable obesity-related phenotypes (lower BMI and lower fat mass [but in Africans only]).

An analysis of the Gln90>Leu variant ${ }^{(12)}$ in extremely obese children and adolescents has provided controversial results. Unlike control normal-weight students, the frequency of Leu90 heterozygotes was significantly higher not only in extremely obese children and adolescents but, also, in underweight students. Finally, Miraglia de Giudice et al.(13) reported that children with at least one Met72 allele became obese significantly earlier than homozygotes for the common Leu72 allele.

The number of studies analyzing behavioral interventions (dietary, physical activity or combined) and weight loss in association with genetic variants is very limited. Nevertheless, results from studies with different designs suggest that variants in the genes for leptin, serotonin receptor and uncoupling protein-1 might be important genetic determinants of individual responsiveness to such interventions (for review, see ${ }^{14,15}$ )

We conclude that there was no association between any of the ghrelin polymorphisms analyzed (Arg51 $>$ Gln, Leu72 > Met and Gln90 > Leu) and changes in biochemical parameters in our interventional study. Nevertheless, in overweight females, the Met72Met genotype of ghrelin might be associated with difficulty losing body weight through behavioral interventions but this genotype is rare in the general population and is not associated with obesity-related phenotypes.

\section{REFERENCES}

1. Kojima M, Hosoda H, Date $Y$, et al. Ghrelin is a growth-hormone-releasing acylated peptide from stomach. Nature 1999;402:656-60.

2. Ukkola O, Pöykkö S. Ghrelin, growth and obesity. Ann Med 2002;34:102-8.

3. Tschöp M, Viswanath D, Weyer C, Tatarani PA, Ravussin E, Heiman ML. Circulating ghrelin levels are decreased in human obesity. Diabetes 2001;50: 707-9.

4. Shiiya T, Nakazato M, Mizuta M, et al. Plasma ghrelin levels in lean and obese humans and the effect of glucose on ghrelin secretion. J Clin Endocrinol Metab 2002; 87:240-4.

5. Cummings DE, Purnell JQ, Frayo RS, Schmidova K, Wisse BE, Weigle DS. A preprandial rise in plasma ghrelin levels suggests a role in meal initiation in humans. Diabetes 2001;50:1714-9.

6. Wren AM, Seal LJ, Cohen MA, et al. Ghrelin enhances appetite and increases food intake in humans. J Clin Endocrinol Metab 2001;86:5992-5.

7. Hinney A, Hoch A, Geller F, et al. Ghrelin gene: Identification of missense variants and a frameshift mutation in extremely obese children and adolescents and healthy normal weight students. J Clin Endocrinol Metab 2002; 87:2716-9.

8. Ukkola O, Ravussin E, Jacobson P, et al. Mutations in the preproghrelin/ghrelin gene associated with obesity in humans. J Clin Endocrinol Metab 2001;86:3996-9.

9. Dvorakova-Lorencova A, Suchanek P, Havel PJ, et al. The decrease in C-reactive protein concentration after diet and physical activity induced weight reduction is associated with changes in plasma lipids, but not interleukin-6 or adiponectin. Metabolism 2006;55:359-65.

10. Miller SA, Dykes DD, Polesky HF. A simple salting out procedure for DNA extraction from human nucleated cells. Nucl Acid Res 1988;16:1215.

11. Ukkola O, Ravussin E, Jacobson P, et al. Role of ghrelin polymorphisms in obesity based on three different studies. Obes Res 2002;10:782-91.

12. Korbonits M, Gueorguiev M, O'Grandy E, et al. A variation in the ghrelin gene increases weight and decreases insulin secretion in tall, obese children. J Clin Endocrinol Metab 2002;87:2716-9.

13. Miraglia de Giudice E, Santoro N, et al. Molecular screening of the ghrelin gene in Italian obese children: the Leu72Met variant is associated with an earlier onset of obesity. Int J Obesity 2004;28:447-50.

14. Hainer V, Bendlová B, Hainerová I, a spol. Úloha genetických faktorů $\mathrm{v}$ patogenezi a léčbě obesity. DMVE 2006; Suppl 1:56-64.

15. Hubacek JA. Nadváha - do jaké míry je ovlivněna geneticky? V: Výživa - nedílná součást léčby závažných chorob. Adámková V, Zimmelová P, red. Ćeské Budějovice: JČU:38-45.

Received 5 March, 2007

Revision accepted 10 April, 2007 